\title{
Factors Determining Farmers' Access to and Sources of Credit: Evidence from the Rain-Fed Zone of Pakistan
}

\author{
Ayat Ullah ${ }^{1,2, *}$, Nasir Mahmood ${ }^{1,3}$, Alam Zeb ${ }^{4}$ and Harald Kächele ${ }^{1,5}$ \\ 1 Research Area 2 "Land Use and Governance”, Working Group: Sustainable Land Use in Developing Countries, \\ Leibniz Centre for Agricultural Landscape Research (ZALF), Eberswalder Straße 84, 15374 Müncheberg, \\ Germany; Nasir.Mahmood@zalf.de (N.M.); harald.kaechele@zalf.de (H.K.) \\ 2 Department of Agricultural Extension Education and Communication, The University of Agriculture, \\ Peshawar, Khyber Pakhtunkhwa 25130, Pakistan \\ 3 Department of Economics and Agricultural Economics, PMAS-Arid Agriculture University, \\ Rawalpindi 46000, Pakistan \\ 4 Department of Renewable Resources, University of Alberta, 751 General Services Building, \\ Edmonton, AB T6G 2H1, Canada; zeb@ualberta.ca \\ 5 Eberswalde University for Sustainable Development, Schicklerstraße 5, 16225 Eberswalde, Germany \\ * Correspondence: Ayat.Ullah@zalf.de; Tel.: +49-3343-282-374
}

Received: 3 October 2020; Accepted: 25 November 2020; Published: 27 November 2020

\begin{abstract}
This study investigates the factors that affect farmers' access to agricultural credit and its role in adopting improved agricultural technologies in the rain-fed zone of Khyber Pakhtunkhwa (KP), Pakistan. Using logistic models, we assess and compare the relative role of farmers' socioeconomic attributes in their access to credit and adoption strategies. The results indicate a moderate positive association between farmers' access to agricultural credit and their adoption of improved agricultural technologies. The binary logit model's results indicate that farmers with a large-sized farm, high farm income, better access to information, and large physical asset ownership showed a positive influence on credit access. However, farming experience showed a negative effect on farmers' access to agricultural credit. Regarding farmers' credit sources, this study found that asset-rich farmers with more farming experience and better access to information relied more on banks than on input providers and informal credit sources. Similarly, older farmers with more education, larger farm sizes and high farm income were more likely to have borrowed from input providers than banks. We conclude that the role of the effective provision of information on credit and agricultural technology is imperative and requires separate policies that are specifically aimed at different groups of farmers with different socioeconomic and farm-related characteristics.
\end{abstract}

Keywords: agricultural credit; adoption of agricultural technologies; rain-fed zone; Khyber Pakhtunkhwa; socioeconomic attributes

\section{Introduction}

The agricultural sector is considered the most crucial sector in developing countries for generating output and employment [1]. Pakistan is a developing country where the economy is heavily dependent on the agricultural sector as a pathway out of poverty and for increasing the profitability and income of small farmers [2,3]. However, the agricultural sector in Pakistan faces many problems, including climate change, uneven rainfall distribution, nutrient deficiency, and the minimal use of improved technological inputs [4]. The adoption of improved technological inputs is considered an important strategy that can increase agricultural productivity and farm income [5]. Limited access 
to credit services, especially in rain-fed environments, has decreased farmers' adoption capacity for improved technologies [6,7]. Such a situation has resulted in poor crop yields, as well as poor income and welfare of farm families [8]. Thus, rural poverty is more common in farming communities where people depend on weather-dependent rain-fed agriculture for their livelihoods $[1,6]$. The adoption of innovations can substantially increase net returns per hectare per cropping season and can reduce poverty by 4.6 percentage points, especially in rain-fed environments [9].

The agricultural sector's growth and sustenance of the agriculture sector depend on farmers' adoption of improved technologies, such as better seeds, pesticides, and farm machinery $[10,11]$. In Pakistan, the adoption of improved technology by farmers is very low, creating a substantial gap between potential and actual crop productivity [12,13]. This is primarily because farmers in Pakistan lack basic resources (such as land and capital), and they are unable to invest in improved agricultural technologies [13]. Access to agricultural financial services such as credit can entice farmers into investing in farm inputs to attain sustainable production and maintain food security [12,14]. On average, agricultural credit improves a farmer's performance by increasing technical efficiency by $3.8 \%$ and reducing the technological gap by providing opportunities for the adoption of better farm inputs [15]. However, formal credit services in Pakistan are poor [16,17]. Usually, landlords and large farmers have access to credit from banks, whereas small farmers rely on informal sources such as friends and relatives [5]. Informal credit sources and input providers are the major (78\%) credit sources for farmers, followed by banks and other formal institutions (15\%) [12]. In the case of small farmers, only $6.5 \%$ have access to bank credit. Complicated bank procedures and security requirements are the main obstacles faced by small and landless farmers in obtaining credit $[18,19]$. Thus, a large number of farmers depend on informal sources of credit compared to formal sources.

Compared to credit borrowed from banks and other formal financial sources, informal loans such as credit borrowed from relatives and friends primarily depend on the strength of family ties and the degree of connection. While taking informal loans, relatives and friends are sometimes forced by the threat of breaking up social ties, which may affect the technical use of informal credit. However, informal loans require a lower interest rate and surety than formal loans, and resource-poor farmers may not be able to afford to contact banks for credit. This ultimately makes informal credit a comparatively attractive option for borrowing [20]. However, formal and informal credits are dominant factors in the improvement of agricultural production and farmers' technical efficiency in Pakistan [21].

Some of the recent studies of $[5,12,14,16,19,20,22-26]$ have focused on the credit demand of farmers, access to formal credit sources, investment in agricultural inputs and long-term welfare by measuring changes in farm productivity, household consumption and agricultural gross domestic product (AGDP). Among these, [5] studied access to formal agricultural credit in Sindh, Pakistan, and found it to be relatively low primarily because of its long distance from formal credit sources, complicated lending procedures and interest rates. Moreover, some other studies $[14,16,22,23]$ have found that various socioeconomic factors, such as gender, age, household size, educational level, farming experience, farm size and income, are among the major determinants of a farmer's access to credit. In addition, several studies [12,20] have reported that because of farmers' poor access to formal credit, most of them rely heavily on informal credit sources, which results in comparatively low investments in farm inputs. A considerable number of studies $[19,24-26]$ have also focused on credit's role in agricultural risk management, farm productivity and agricultural gross domestic product (AGDP) and have found positive and significant impacts on all three aspects. A lack of proper access to credit facilities ultimately incapacitates farmers in obtaining potential farming revenues, as reported by [14] i.e., poor access to credit negatively affects farmers' welfare and income.

However, the socioeconomic impacts of farmers' access to and sources of credit and their correlations with improved agricultural technologies in rain-fed environments have not yet been measured. Therefore, the present study attempts to estimate the impacts of farmers' socioeconomic characteristics in shaping farmers' access to and choice of credit sources, as well as its correlation with technology adoption in rain-fed farming in Pakistan. Understanding the factors that influence 
farmers' adoption of modern technologies and choice of credit sources is essential in planning and executing agricultural credit-related policies and programs for meeting the challenges of food security in developing countries.

In this paper, we explore quantitatively the effect of different socioeconomic, technical and institutional factors on farmers' access to credit, adoption of improved technology and choice of credit sources in the KP's rain-fed zone. This information will ultimately help form policies that aim to reduce rural poverty by facilitating farmers' easy and affordable access to credit. Specifically, this study focuses on the following objectives: (1) to assess the relationship between access to credit and adoption of improved agricultural technology; (2) to determine the factors that influence farmers' access to agricultural credit; and (3) to explore the effect of socioeconomic, technical and institutional factors on farmers' choice of credit sources. The current study makes a significant contribution to the existing literature on the determinants of farmers' access and choice of credit sources by using a primary data set.

\section{Materials and Methods}

\subsection{Study Area}

Since the study's focus is rain-fed agriculture, the two rain-fed districts of the KP Province of Pakistan, Lakki Marwat and Karak, comprise the area of study (Figure 1). The Lakki Marwat district has 116,900 ha of total cultivated land, whereas District Karak has 75,642 ha. In the study area, most of the cultivated land is under rain-fed conditions, with sandy soil types and relatively hot weather. District Lakki Marwat is situated between $32^{\circ} 61^{\prime} \mathrm{N}$ and $70^{\circ} 91^{\prime} \mathrm{E}$ at an altitude of $200-1000 \mathrm{~m}$ above sea level, while the Karak district is situated at $32^{\circ} 47^{\prime}$ to $33^{\circ} 28^{\prime} \mathrm{N}$ and $70^{\circ} 30^{\prime}$ to $71^{\circ} 30^{\prime}$ E. Agriculture is the primary economic activity, and the main crops in the study area are wheat and gram [27].

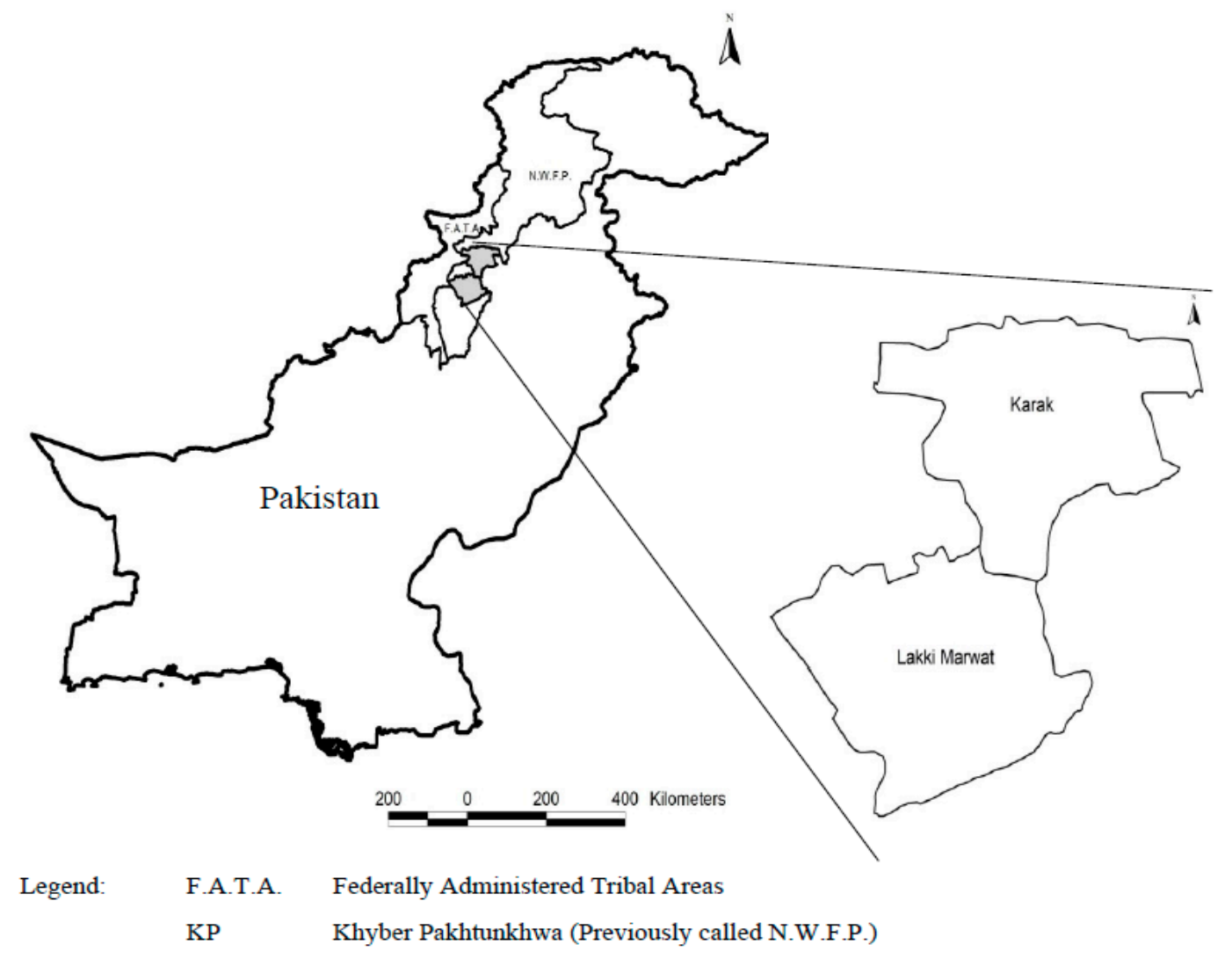

Figure 1. Map of the study area. 


\subsection{Data and Sampling}

A household survey was conducted during the growing season from September to November 2017 using a pretested questionnaire. A total of 395 respondents were randomly selected from a list of farmers obtained from the local agricultural extension, population and revenue departments of both districts. The principal author collected the data using a face-to-face interview method and a pre-set list of questions. The questionnaire developed was pretested by administering it to 20 households that were not included in the final survey. The final questionnaire was modified based on the pre-test survey. The questionnaire contained questions related to farmers' credit sources, access to information on credit sources, socioeconomic conditions, institutional factors and adoption of agricultural technologies. Farmers in the study area either borrowed from banks or other informal sources and input providers. Regarding agricultural technology adoption, farmers were specifically asked about the technology they had adopted during the previous two years. Any farmer who adopted at least one form of technology (from those recommended by the local agriculture extension department) was considered an adopter. The total sample size for the study was calculated using Yamane's formula [28]. This formula depends on the population size, and the level of precision has been widely used by researchers $[11,13,17]$ for data collection.

\subsection{Variables and Expectations}

Our statistical analysis relies on a binary response variable, indicating whether a farmer has access to credit for adopting improved agricultural technologies, as well as a continuous response variable of farmers' socioeconomic characteristics. Following [29], credit sources were classified into formal sources (banks), informal sources (friends and relatives) and input providers (seed and pesticides dealers). Farmers in the study area used only one source of credit at a time. They either relied on banks, input providers or informal sources depending on their particular socioeconomic characteristics and the prevailing institutional attributes (Figure 2). Predictor variables for statistical analysis in the study were drawn based on previous studies. Our empirical model included farmers' socioeconomic attributes and a set of technical and institutional factors that may have impacted farmers' access to agricultural credit and credit sources. For instance, previous studies showed that age, the education level of the household's head, farm size, access to information and farmer asset status influenced their access to credit [30]. Similarly, [31] reported that household size, farming experience, farm income and interest rate affected farmers' access to credit. Moreover, $[5,12,14,16,23,25,26]$ reported that farmers' institutional factors (such as extension departments and other institutions providing information to farming communities) and socioeconomic factors such as age, education of the household head, household size, farm size, farm income and farming experience affected farmers' access to agricultural credit and adoption of improved agricultural technologies. This study will focus on the socioeconomic factors affecting farmers' access to and sources of credit and their effects on farmers' adoption of agricultural technologies.

\subsection{Binary Logit Model}

The study by [32] specified that a binary logistic model is employed when the dependent variable is in binary form. Therefore, we used a logit model to explain the relationship between a binary variable indicating whether farmers have access to credit and a set of explanatory variables representing farmers' socioeconomic characteristics and the associated institutional factors.

\subsection{Multinomial Logit Model}

Farmers can use multiple agricultural credit sources, such as banks, friends, relatives and input dealers. Therefore, we use a multinomial logit model to identify the multiple types of credit sources used by the respondents. In the multinomial logit model, various types of credit sources are considered dependent variables, and the independent variables include farmers' socioeconomic attributes and a set 
of technical and institutional factors. The multinomial logit model was used to identify the determinants of farmers' credit sources because the dependent variable has more than two outcomes [33].

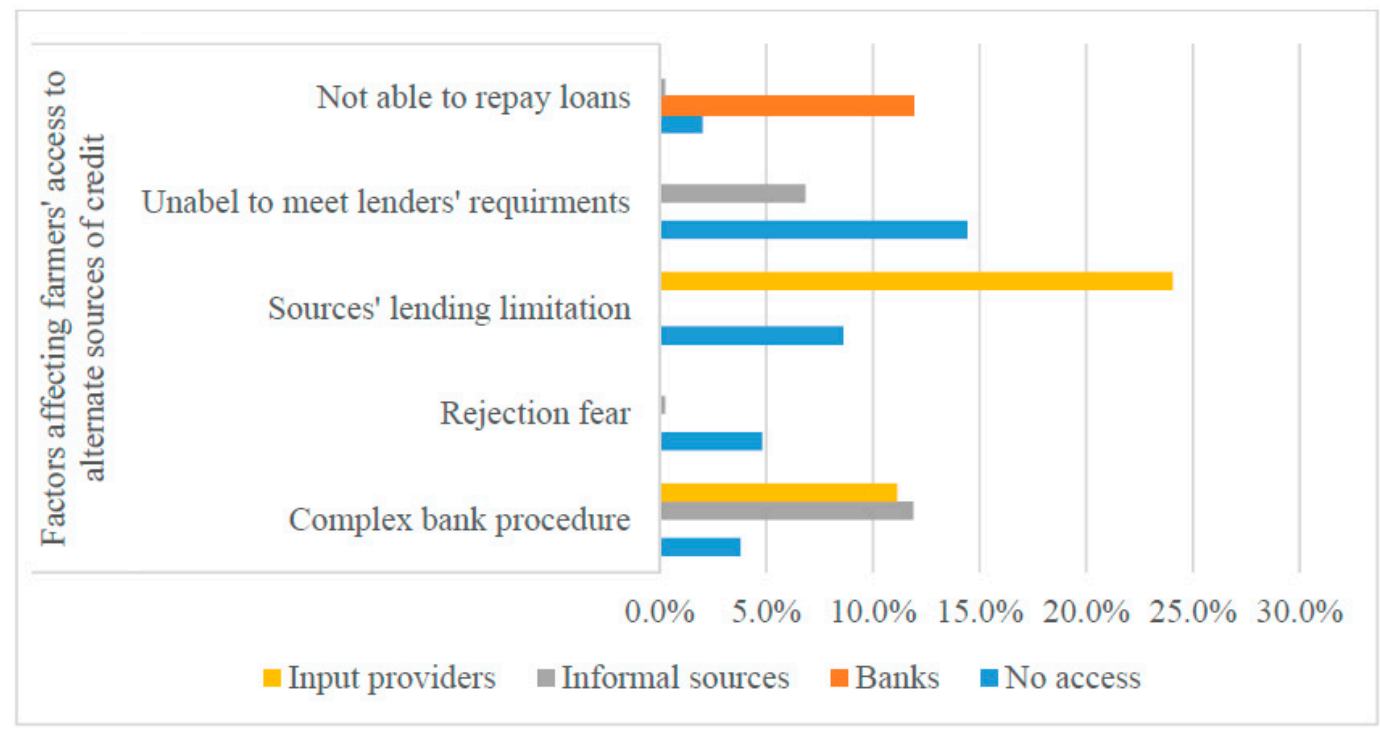

Figure 2. Factors affecting farmers' access to alternate sources of credit.

\section{Results and Discussion}

\subsection{Sample Overview and Summary Statistics}

The results in Table 1 present the summary statistics of the explanatory variables used in the analysis. The results revealed that farmers' access to formal credit was low, as only $11.90 \%$ of the sampled respondents had access to formal sources. Approximately $33.67 \%$ of the respondents showed no access to credit from any source. This provides support for examining the factors that affect farmers' access to agricultural credit from formal sources such as banks. The results also showed that $35.19 \%$ of the respondents received credit for agricultural use from input providers, while the remaining $19.24 \%$ of respondents received credit from informal sources, such as relatives and friends.

There were significant mean differences between access and no-access farmers in terms of age, farm size, farming experience and monthly farm income. On average, farmers with access to credit were 49.16 years old and had a farming experience of 33.29 years. However, farmers with no access were less experienced and comparatively young (Table 1 ). Moreover, the mean farm size of farmers with access was 29.79 acres, with a monthly farm income of 33,524.63 Pakistani rupees, relatively higher than the no-access farmers (Table 1). In this study, a household's access to information showed a strong influence on credit access. For example, 98 respondents who showed access to credit information also showed access to credit (Table 1). However, most (321) considered the interest rate to be a large hurdle in access to credit and borrowing (Table 1) and might have used friends and family members as credit sources. Out of a total of 106 respondents who had assets, 93 showed access to credit. There was a significant association between farmers' access to credit and institutional and other factors (see Table 1).

Some variables, such as access to credit-specific extension services, use of cell phones for information on credit and information on credit from mass media (television, radio and social media) was merged as 'access to information' for the ease of the farmers included in this study. This is done because most of the farmers were illiterate and were unable to respond to the aforementioned multiple questions. An important variable, 'gender' is also not included in the study because male family members headed all the farms. The area under investigation is a tribal area where females usually do not come out of their houses and are not even allowed to work due to their traditional values. 
Table 1. Sample overview and summary statistics.

\begin{tabular}{|c|c|c|c|}
\hline Variables & With Access & Without Access & Test Statistics \\
\hline $\begin{array}{l}\text { Farmers socioeconomic } \\
\text { attributes }\end{array}$ & Mean & Mean & $t$-test \\
\hline Age of household head & $49.16(13.66)$ & $42.54(15.24)$ & $4.374^{* * *}$ \\
\hline Education of household head & $3.77(5.12)$ & $3.56(4.30)$ & 0.415 \\
\hline Household size & $13.11(5.64)$ & $12.16(5.74)$ & 1.570 \\
\hline Farm size & $29.79(28.99)$ & $19.19(14.43)$ & $3.970 * * *$ \\
\hline Farming experience & $33.29(13.67)$ & $25.82(12.95)$ & $5.223 * * *$ \\
\hline Monthly farm income & $33524.63(32478.38)$ & $16860.13(13881.54)$ & $5.658^{* * *}$ \\
\hline Institutional and other factors & No. & No. & $\chi^{2}$-test \\
\hline Access to information & $97(24.6)$ & $1(0.3)$ & $62.056^{* * *}$ \\
\hline Interest rate & $192(48.6)$ & $129(32.7)$ & $32.492 * * *$ \\
\hline Asset status & $93(13.5)$ & $13(3.3)$ & $29.727^{* * *}$ \\
\hline Credit sources & No. & - & Percentage $(\%)$ \\
\hline Banks & 47 & - & 11.90 \\
\hline Relatives and friends & 76 & - & 19.24 \\
\hline Inputs Providers & 139 & - & 35.19 \\
\hline No access & 133 & - & 33.67 \\
\hline
\end{tabular}

\subsection{Association of Credit Access and Technology Adoption}

In the total sampled households, 187 farmers adopted at least one new agriculture-related technology. The association between access to credit and farmers' adoption of improved technology is given in Table 2. The results show a strong association between both variables $\left(\chi^{2}=94.411\right.$, significance $=0.000)$. A Yule's $Q$ value $(0.674)$ shows a moderate positive association between farmers' credit access and the adoption of improved agricultural technologies. Thus, this proves a positive association between farmers' credit access and the adoption of improved agricultural technologies. This result is in line with the findings of studies conducted in other regions of Pakistan. For example, Ref.[15] observed a positive relationship between access to credit and improved technology adoption. However, farmers in the study province have significantly lower access to agricultural financial services (all banks, input providers and informal), which affects the adoption of improved technologies [34].

Table 2. Farmers' credit access and adoption of improved technology.

\begin{tabular}{|c|c|c|c|c|c|}
\hline \multirow{2}{*}{ Adoption Status } & \multicolumn{4}{|c|}{$\chi^{2}$-Test } & \multirow{2}{*}{$\begin{array}{l}\text { Yule's Q Test } \\
\text { Yule's Value }\end{array}$} \\
\hline & Access & No Access & Total & $\chi^{2}$ Value & \\
\hline Adopters & $157(39.7)$ & $30(7.6)$ & $187(47.3)$ & \multirow{3}{*}{$94.411^{* * *}$} & \multirow{3}{*}{0.674} \\
\hline Non-adopters & 105 (26.6) & $103(26.1)$ & $208(52.7)$ & & \\
\hline Total & $262(66.3)$ & 133 (33.7) & $395(100.0)$ & & \\
\hline
\end{tabular}

\subsection{Farmers' Perceptions of the Factors Affecting Their Access to Multiple Credit Sources and Adoption}

Famers in the study area used one source of credit at a time from the three available sources. According to the farmers, the choice of a source is not self-selected or preferred but rather depends on many factors. In most cases, the factors identified by the farmers were identical (Figure 2). For example, farmers $(12 \%)$ who relied on informal sources and input providers believed that the bank credit acquisition procedure was complex and time consuming. However, they considered the adoption 
of improved technologies as a prerequisite for increased productivity. Therefore, for some farmers, input providers, friends and relatives were the preferred choice. However, farmers believe that these credit sources are sometimes inadequate and therefore fail to adopt (and are unable to invest in) improved technologies. Many farmers did not contact any credit source at all because they had already been denied credit without any stated reason. For these farmers, the lack of reliable credit sources was the main hurdle in the adoption of improved agricultural technologies (Figure 2).

Comparatively, a high percentage $(24 \%)$ of farmers approached input providers for credit. The main reason for using input providers as a primary credit source was the lending limits of banks, relatives and friends. In most cases, friends, relatives and even banks were unable to provide the required credit amount. For larger loans, bank collateral requirements are high, and small farmers are unable to meet these. Additionally, many farmers are reluctant to use any credit source to adopt new and improved crop technologies because of crop failure. The area is rain-fed, and low crop productivity will leave them unable to repay their debts. Policies focusing on easy access to bank loans will greatly increase small farmers' ability to adopt improved agriculture technologies.

\subsection{Determinants of Farmers' Access to Credit}

The binary logit model's results indicate that farm size, farming experience, farm income, access to information, and farmers' asset status are significantly related to farmers' access to agricultural credit (Table 3).

Table 3. Results of binary logit model.

\begin{tabular}{|c|c|c|c|c|}
\hline Variables & Coefficient & Standard Error & Wald- $\chi^{2}$ & Odds Ratio \\
\hline Farmers socioeconomic attributes & - & - & - & - \\
\hline Age of household head & 0.006 & 0.017 & 0.148 & 1.006 \\
\hline Education of household head & 0.022 & 0.030 & 0.554 & 1.022 \\
\hline Household size & 0.037 & 0.025 & 2.186 & 1.037 \\
\hline Farm size & $0.022 *$ & 0.013 & 2.745 & 1.022 \\
\hline Farming experience & $-0.032 *$ & 0.018 & 3.098 & 0.968 \\
\hline Monthly farm income & $0.000 * * *$ & 0.000 & 18.581 & 1.000 \\
\hline Institutional and other factors & - & - & - & - \\
\hline Access to information & $4.159^{* * *}$ & 1.176 & 12.515 & 63.993 \\
\hline Interest rate & 0.737 & 0.681 & 1.172 & 2.091 \\
\hline Asset status & $1.017^{* * *}$ & 0.432 & 5.542 & 2.765 \\
\hline \multicolumn{5}{|l|}{ Observations $=395$} \\
\hline
\end{tabular}

The model showed a positive and significant effect of farm size on farmers' access to credit. Farm size is considered a symbol of social status in Pakistan. Therefore, farmers with large farm sizes are more likely to have access to agricultural credit [35]. This is consistent with previous studies $[16,22,23,35]$ that found a significant positive effect of farm size on farmers' access to credit. In Pakistan, farmers' access to formal sources is limited. The main reason for the lack of access to formal credit sources is the high collateral requirements in the form of land and rarely available personal guarantees [35]. However, the findings of our study are in contrast with the findings of [5,14], who reported a significant negative effect of farm size on access to credit.

Farmers with less farming experience have more access to credit, implying that as farmers' farming experience increases, their access to credit decreases. The observed phenomenon contrasts with the findings of [16], who studied a positive relationship between farming experience and access 
to agricultural credit. A plausible explanation for the lower access of experienced farmers could be the age factor. Old age farmers in the study area practise subsistence agriculture with traditional tools and means.

Farmers with more income from agriculture are more likely to have access to agricultural credit. This may be because farmers with less income from agriculture may engage in subsistence agriculture with fewer assets, small landholding size, and less access to extension services and information. This result is in agreement with the findings of $[15,16]$, who also observed a positive and significant relationship between agricultural income and farmers' access to credit. Contrary to our findings, the findings of [35] revealed that monthly farm income and access to agricultural credit were negatively associated with each other.

Our results show access to information as an important variable that affects farmers' access to credit. Farmers with access to information on banks' credit procedures and requirements were more likely to have access to credit. This means that farmers who received information and extension services have better access to agricultural credit than those with no access to information. This result is in agreement with the findings of $[14,23]$, who found more access to agricultural credit among farmers with access to information.

Our results show that asset ownership positively influenced farmers' access to credit. As the assets of a farmer increase, the farmer will be more likely to have access to credit. Possessions of assets by farmers increase the probability of their access to credit as well; as a farmer's assets increase, lenders become more willing to grant loans based on the understanding that these farmers would repay the loans on time. Additionally, institutions require assets such as houses, family members' government jobs, or guarantors to provide the credit that farmers lack access to. Our study results are in agreement with the previous findings of $[23,24]$ that reported the asset-holding status of a farmer impacts the farmer's access to credit.

\subsection{Determinants of Farmers' Choice of Credit Sources for the Adoption of Agricultural Technologies}

A multinomial logit model was applied to estimate the factors determining farmers' choice of credit, mainly for the adoption of new agricultural technologies. In the analysis, 'bank' was used as a reference category. First, we performed likelihood ratio chi-square test statistics and found them to be significant $(p=0.000)$, indicating high goodness of fit. The existence of multicollinearity was tested among explanatory variables using the variance inflation factor and contingency coefficient for continuous and dummy variables, respectively, and no multicollinearity was observed.

The respondent's age has a significant and positive effect on farmers' access to credit from input providers. This means that as a farmer's age increases, the probability of the farmer gaining access to credit from input providers increases. The study in [11] reported that farmers with access to credit from agricultural input providers face information asymmetry on farm inputs; however, aged farmers comparatively face information asymmetry at a low level on the prices of agricultural inputs. Therefore they may use input providers as credit sources. However, this finding contrasts with those of [36], who found that age, a proxy for experience, had a positive and significant influence on farmers' access to formal credit compared to informal and input providers' sources.

Furthermore, a household head's education is also significantly and positively associated with farmers' access to agricultural credits from input providers. The household head's level of education is an indicator of literacy and affects farmer awareness and understanding of credit sources. Additionally, it is less likely for input providers to exploit an educated farmer [11]. This is contrary to the findings of [36,37], whose findings suggest that more educated farmers have access to formal credit sources compared to other sources, such as informal sources. The reason for this could be due to complicated bank procedures, driving even educated farmers to input providers for credit.

Farm size is significantly and positively associated with farmers' access to credit from input providers compared to banks. This means that as the farm size increases, the probability of farmers' access to credit from input providers also increases, which can positively affect farmers' adoption 
of agricultural technologies. This is similar to [38], who also found a non-significant association between farm size and farmers' access to credit from banks. However, the finding is contrary to a study by [36,37], who showed a positive and significant likelihood of farmers' access to institutional sources such as banks compared to informal and input provider sources. The study by [36] argued that farm size denotes the scale of production and is an important factor from which farmers can command other resources that positively affect farmers' access to credit from banks. Research by [37] found that although farmers' access to credit from banks increases with increasing farm size, after a certain point, the probability of farmers accessing credit from banks decreases with increasing farm size.

The monthly farm income of a farm household has a significant and positive impact on access to credit from input providers (Table 4). The effect of farm income on access to credit from input providers showed that an increase in household farm income could increase the probability of farmers' access to credit from input providers. The study by [39] found that income positively affects a farmers' access to agricultural credit since farmers can use farm income to manage risks in credit access and adopt improved agricultural technologies. This finding is also in line with the results of [36,37], who found that income has a positive relationship with farmers' access to credit from non-institutional sources.

Table 4. Results of the multinomial logit model.

\begin{tabular}{lcccc}
\hline \multirow{2}{*}{ Variables } & \multicolumn{2}{c}{ Friends and Relatives } & \multicolumn{2}{c}{ Inputs Providers } \\
\cline { 2 - 5 } & Coefficient & Standard Error & Coefficient & Standard Error \\
\hline Farmers socioeconomic attributes & - & - & - & - \\
\hline Age of household head & 0.049 & 0.052 & $0.090^{*}$ & 0.052 \\
Education of household head & 0.056 & 0.072 & $0.162^{* *}$ & 0.072 \\
Household size & 0.047 & 0.061 & -0.028 & 0.059 \\
Farm size & -0.013 & 0.017 & $0.026^{*}$ & 0.015 \\
Farming experience & $-0.114^{* *}$ & 0.052 & $-0.154^{* * *}$ & 0.053 \\
Monthly farm income & 0.000 & 0.000 & $0.000^{* * *}$ & 0.000 \\
\hline Institutional and other factors & - & - & - & - \\
\hline Access to information & $-4.281^{* * *}$ & 0.821 & $-4.208^{* * *}$ & 0.855 \\
Interest rate & 0.622 & 0.687 & 0.993 & 0.702 \\
Asset status & -0.575 & 0.647 & $-1.847^{* * *}$ & 0.651 \\
\hline
\end{tabular}

Log likelihood $=347.50$. LR chi/square $=1333.59$. Chi/square sig $=0.000$. Pseudo $\mathrm{R}^{2}=0.568$. The reference category is 'bank'. ${ }^{* * *},{ }^{* *}$ and ${ }^{*}$ show significance at $1 \%, 5 \%$ and $10 \%$, respectively. Sample size $=262$. The dependent variable is farmers' sources of credit.

A farmer's experience negatively impacts their decision to use friends and relatives as their credit sources compared to banks. This means that as the farming experience of a farmer increases, the likelihood of his access to banks compared to input providers and informal credit sources also increases. Experienced farmers have better opportunities in accessing banks. Thus as farming experience increases, they will more likely move from input providers and informal sources to banks. This is similar to the findings of $[37,38]$, as they reported that an increase in farming experience decreases the probability of a farmer being credit-constrained by banks, while the probability of their being constrained by input providers and informal sources will increase.

Access to information is an important variable that affects farmers' access to and sources of agricultural credit and affects the adoption of agricultural technologies. The results showed that, as expected, access to information on credit and innovations impacted farmers' access to credit (Table 4). That is, a farmer who has better access to information (i.e., seeds, fertilisers, machinery, credit availability and procedures for obtaining credit) has better access to credit from banks than informal sources and input providers. Farmers with better access to information showed a higher probability of access to bank credit compared with other sources. Being well informed about each credit source's advantages, procedures, and technological availability increased a farmer's likelihood 
of borrowing from banks and adopting technology (Table 4). These findings are similar to the findings of other studies [37,38,40,41].

The result in Table 4 shows that ownership of assets has a positive relationship with a farmers' access to banks compared to input providers. The study in $[42,43]$ found that ownership of assets has a significant and positive association with farmers' access to credit from banks. As a farmer's assets increase, they will more likely move from input providers to banks. This is also similar to [36], who found that farmer asset status was positively associated with access to credit from banks compared to other sources. This may be because possession of assets positively impacts lenders' assessments of a farmer's creditworthiness and repayment capacity.

\section{Conclusions and Policy Recommendations}

This study examines the association between farmers' access to agricultural credit and the impact on the adoption of improved agricultural technology. This study was conducted in the rain-fed rural areas of KP Province. Through the use of a binary logit model, we also pinpoint the factors that influence this association. The results indicate that access to agricultural credit plays an important role in farmers' adoption of improved agricultural technology (i.e., access to credit leads to technology adoption). However, access to agricultural credit is influenced by several factors. The study's findings revealed that farm size, monthly income, access to information, and asset status depicted positive effects, whereas farming experience showed negative impacts regarding access to credit.

This study also used a multinomial logit model to identify factors that influenced a farmer's choice of credit sources. Farmers' choice of credit source and the factors determining a specific choice have rarely been investigated in Pakistan. The present study attempts to fill this gap by analysing different choice constraints among the various credit sources. The impact of different socioeconomic, technical and institutional variables shows that credit strategies are diversified. Farmers contact different institutions, including formal (banks), informal (relatives and friends) and input providers, to obtain agricultural credit. Farmers' asset status, access to information and awareness of it, and farming experience contribute to choosing banks over relatives and friends as credit sources. Similarly, older farmers with more education, larger farm sizes and high farm income tend to use input providers as a credit source over banks.

This implies the need to enhance farmers' access to credit to adopt improved agricultural technologies effectively. In this case, the role of effective provision of information on credit and innovations is imperative. Moreover, the adoption of improved agricultural technologies will create opportunities for improvement in farms and the farmers' socioeconomic factors, which are important for boosting farmers' access to credit and further technology adoption. Therefore, improvement in farmers' access to credit and adoption will require separate policies that are specifically aimed at different groups of farmers with different socioeconomic and farm-related characteristics. Efforts to promote agricultural technology adoption require access to credit, which must move beyond a single source, especially to formal sources, since credit access could play an important role in shaping farmers' attitudes towards agricultural technology adoption. The area is rain-fed, and crop failure is common due to low soil fertility and rain-fed conditions (i.e., there is a heavy dependency on sufficient rainfall). Polices focusing on crop insurance for small farmers and subsidized input provision will help farmers adopt new technologies. Additionally, policies focusing on easy access to bank credit will greatly increase farmers' ability to adopt improved agriculture technologies.

Author Contributions: Conceptualization, A.U.; methodology, A.U.; software, N.M.; formal analysis, N.M.; investigation, A.U. and N.M.; data curation, A.Z.; writing—original draft preparation, A.U.; writing-review and editing, N.M. and A.Z.; supervision, H.K.; funding acquisition A.U. All authors have read and agreed to the published version of the manuscript.

Funding: This research was funded by Higher Education Commission (HEC) of Pakistan, grant number I-8/HEC/HRD/2017/7900 and The APC was funded by Leibniz Centre for Agricultural Landscape Research (ZALF), Müncheberg, Germany. 
Acknowledgments: The first author acknowledges the Humboldt University of Berlin and Leibniz Centre for Agricultural Landscape Research (ZALF) for providing technical and administrative assistance during the span of this research work and the Higher Education Commission of Pakistan (HEC) for providing financial support.

Conflicts of Interest: The authors declare no conflict of interest.

\section{References}

1. Mahmood, N.; Arshad, M.; Kaechele, H.; Ma, H.; Ullah, A.; Müller, K. Wheat yield response to input and socioeconomic factors under changing climate: Evidence from rainfed environments of Pakistan. Sci. Total Environ. 2019, 688, 1275-1285. [CrossRef] [PubMed]

2. Kirby, M.; Mainuddin, M.; Khaliq, T.; Cheema, M.J.M. Agricultural production, water use and food availability in Pakistan: Historical trends, and projections to 2050. Agric. Water Manag. 2017, 179, 34-46. [CrossRef]

3. Mellor, J.W.; Malik, S.J. The impact of growth in small commercial farm productivity on rural poverty reduction. World Dev. 2017, 91, 1-10. [CrossRef]

4. Mahmood, N.; Arshad, M.; Kaechele, H.; Shahzad, M.F.; Ullah, A.; Mueller, K. Fatalism, Climate Resiliency Training and Farmers' Adaptation Responses: Implications for Sustainable Rainfed-Wheat Production in Pakistan. Sustainability 2020, 12, 1650. [CrossRef]

5. Chandio, A.A.; Jiang, Y. Determinants of Credit Constraints: Evidence from Sindh, Pakistan. Emerg. Mark. Financ. Trade 2018, 54, 3401-3410. [CrossRef]

6. Gentle, P.; Maraseni, T.N. Climate change, poverty and livelihoods: Adaptation practices by rural mountain communities in Nepal. Environ. Sci. Policy 2012, 21, 24-34. [CrossRef]

7. Tippe, D.E.; Rodenburg, J.; Schut, M.; van Ast, A.; Kayeke, J.; Bastiaans, L. Farmers' knowledge, use and preferences of parasitic weed management strategies in rain-fed rice production systems. Crop Prot. 2017, 99, 93-107. [CrossRef]

8. Mahmood, N.; Arshad, M.; Kaechele, H.; Ullah, A.; Müller, K. Economic efficiency of rainfed wheat farmers under changing climate: Evidence from Pakistan. Environ. Sci. Pollut. Res. 2020, 27, 34453-34467. [CrossRef]

9. Wossen, T.; Alene, A.; Abdoulaye, T.; Feleke, S.; Rabbi, I.Y.; Manyong, V. Poverty reduction effects of agricultural technology adoption: The case of improved cassava varieties in Nigeria. J. Agric. Econ. 2019, 70, 392-407. [CrossRef]

10. Ali, A.; Rahut, D.B.; Behera, B.; Imtiaz, M. Farmers' access to certified wheat seed and its effect on poverty reduction in Pakistan. J. Crop Improv. 2015, 29, 247-265. [CrossRef]

11. Ullah, A.; Arshad, M.; Kächele, H.; Zeb, A.; Mahmood, N.; Müller, K. Socio-economic analysis of farmers facing asymmetric information in inputs markets: Evidence from the rainfed zone of Pakistan. Technol. Soc. 2020, 63, 101405. [CrossRef]

12. Elahi, E.; Abid, M.; Zhang, L.; ul Haq, S.; Sahito, J.G.M. Agricultural advisory and financial services; farm level access, outreach and impact in a mixed cropping district of Punjab, Pakistan. Land Use Policy 2018, 71, 249-260. [CrossRef]

13. Ullah, A.; Arshad, M.; Kachele, H.; Khan, A.; Mahmood, N.; Müller, K. Information asymmetry, input markets, adoption of innovations and agricultural land use in Khyber Pakhtunkhwa, Pakistan. Land Use Policy 2020, 90, 104261. [CrossRef]

14. Lakhan, G.R.; Channa, S.A.; Magsi, H.; Koondher, M.A.; Wang, J.; Channa, N.A. Credit constraints and rural farmers' welfare in an agrarian economy. Heliyon 2020, 6, e05252.

15. Abdallah, A.H. Agricultural credit and technical efficiency in Ghana: Is there a nexus? Agric. Financ. Rev. 2016, 76, 309-324. [CrossRef]

16. Chandio, A.A.; Jiang, Y.; Wei, F.; Rehman, A.; Liu, D. Famers' access to credit: Does collateral matter or cash flow matter?-Evidence from Sindh, Pakistan. Cogent Econ. Financ. 2017, 5, 1369383. [CrossRef]

17. Hussain, A.; Thapa, G.B. Smallholders' access to agricultural credit in Pakistan. Food Secur. 2012, 4, 73-85. [CrossRef]

18. Burton, M.; Fileccia, T.; Gulliver, A.; Qamar, M.; Tayyab, A. Pakistan: Priority Areas for Investment in the Agricultural Sector. FAO Investment Centre, Country Highlights (FAO). 2012. Available online: http://www.fao.org/3/i2879e/i2879e.pdf (accessed on 27 September 2020).

19. e Saqib, S.; Ahmad, M.M.; Panezai, S.; Ali, U. Factors influencing farmers' adoption of agricultural credit as a risk management strategy: The case of Pakistan. Int. J. Disaster Risk Reduct. 2016, 17, 67-76. [CrossRef] 
20. Karaivanov, A.; Kessler, A. (Dis)advantages of informal loans-Theory and evidence. Eur. Econ. Rev. 2018, 102, 100-128. [CrossRef]

21. Chandio, A.A.; Jiang, Y.; Gessesse, A.T.; Dunya, R. The nexus of agricultural credit, farm size and technical efficiency in Sindh, Pakistan: A stochastic production frontier approach. J. Saudi Soc. Agric. Sci. 2019, 18, 348-354. [CrossRef]

22. Nouman, M.; Siddiqi, M.; Asim, S.; Hussain, Z. Impact of socio-economic characteristics of farmers on access to agricultural credit. Sarhad J. Agric. 2013, 29, 469-476.

23. Rasheed, R.; Xia, L.C.; Ishaq, M.N.; Mukhtar, M.; Waseem, M. Determinants influencing the demand of microfinance in agriculture production and estimation of constraint factors: A case from south Region of Punjab Province, Pakistan. Int. J. Agric. Ext. Rural Dev. Stud. 2016, 3, 45-58.

24. Saleem, M.A.; Jan, F.A. The impact of agricultural credit on agricultural productivity in Dera Ismail Khan (District) Khyber Pakhtonkhawa Pakistan. Eur. J. Bus. Manag. 2011, 3, 38-44.

25. Rehman, A.; Chandio, A.A.; Hussain, I.; Jingdong, L. Is credit the devil in the agriculture? The role of credit in Pakistan's agricultural sector. J. Financ. Data Sci. 2017, 3, 38-44. [CrossRef]

26. Chandio, A.A.; Jiang, Y.; Rehman, A. Credit margin of investment in the agricultural sector and credit fungibility: The case of smallholders of district Shikarpur, Sindh, Pakistan. Financ. Innov. 2018, 4, 27. [CrossRef]

27. Ullah, A.; Khan, A. Effect of extension-farmers contact on farmers' knowledge of different pest management practices in the rain-fed districts of Khyber Pakhtunkhwa, Pakistan. Sarhad J. Agric. 2019, 35, 602-609. [CrossRef]

28. Yamane, T. Statistics: An Introductory Analysis, 2nd ed.; Harper and Row: New York, NY, USA, $1967 ;$ p. 886.

29. Hua, X.; Yan, J.; Zhang, Y. Evaluating the role of livelihood assets in suitable livelihood strategies: Protocol for anti-poverty policy in the Eastern Tibetan Plateau, China. Ecol. Indic. 2017, 78, 62-74. [CrossRef]

30. Barslund, M.; Tarp, F. Formal and informal rural credit in four provinces of Vietnam. J. Dev. Stud. 2008, 44, 485-503. [CrossRef]

31. Ojo, T.O.; Baiyegunhi, L.J.S. Determinants of credit constraints and its impact on the adoption of climate change adaptation strategies among rice farmers in South-West Nigeria. J. Econ. Struct. 2020, 9, 1-15. [CrossRef]

32. Gujarati, D.N.; Porter, D.C. Basic Econometrics, 4th ed.; The MacGraw Hill: New York, NY, USA, 2003.

33. Danso-Abbeam, G.; Baiyegunhi, L.J. Welfare impact of pesticides management practices among smallholder cocoa farmers in Ghana. Technol. Soc. 2018, 54, 10-19. [CrossRef]

34. Ullah, R.; Shivakoti, G.P.; Zulfiqar, F.; Iqbal, M.N.; Shah, A.A. Disaster risk management in agriculture: Tragedies of the smallholders. Nat. Hazards 2017, 87, 1361-1375. [CrossRef]

35. Saqib, S.E.; Kuwornu, J.K.M.; Panezia, S.; Ali, U. Factors determining subsistence farmers' access to agricultural credit in flood-prone areas of Pakistan. Kasetsart J. Soc. Sci. 2018, 39, 262-268. [CrossRef]

36. Kumar, A.; Das, R.; Aditya, K.S.; Bathla, S.; Jha, G.K. Examining institutional credit access among agricultural households in Eastern India: Trends, patterns and determinants. Agric. Financ. Rev. 2020. [CrossRef]

37. Moahid, M.; Maharjan, K.L. Factors Affecting Farmers' Access to Formal and Informal Credit: Evidence from Rural Afghanistan. Sustainability 2020, 12, 1268. [CrossRef]

38. Kofarmata, Y.I.; Danlami, A.H. Determinants of credit rationing among rural farmers in developing areas. Agric. Financ. Rev. 2019, 9, 158-173. [CrossRef]

39. Akhtar, S.; Li, G.; Nazir, A.; Razzaq, A.; Ullah, R.; Faisal, M.; Naseer, M.A.U.R.; Raza, M.H. Maize production under risk: The simultaneous adoption of off-farm income diversification and agricultural credit to manage risk. J. Integr. Agric. 2019, 18, 460-470. [CrossRef]

40. Belay, A.; Recha, J.W.; Woldeamanuel, T.; Morton, J.F. Smallholder farmers' adaptation to climate change and determinants of their adaptation decisions in the Central Rift Valley of Ethiopia. Agric. Food Secur. 2017, 1, 24. [CrossRef]

41. Shiferaw, B.; Kebede, T.; Kassie, M.; Fisher, M. Market imperfections, access to information and technology adoption in Uganda: Challenges of overcoming multiple constraints. Agric. Econ. 2015, 46, 475-488. [CrossRef]

42. Pal, D.; Laha, A.K. Credit off-take from formal financial institutions in rural India: Quantile regression results. Agric. Food Econ. 2014, 2, 9. [CrossRef] 
43. Abedullah, N.; Khalid, M.; Kouser, S. The role of agricultural credit in the growth of livestock sector: A case study of Faisalabad. Pakistan Vet. J. 2009, 29, 81-84.

Publisher's Note: MDPI stays neutral with regard to jurisdictional claims in published maps and institutional affiliations.

(C) 2020 by the authors. Licensee MDPI, Basel, Switzerland. This article is an open access article distributed under the terms and conditions of the Creative Commons Attribution (CC BY) license (http://creativecommons.org/licenses/by/4.0/). 